\title{
Occupational exposure to blood and bodily fluids among healthcare workers in Serbian general hospitals
}

\author{
Bojana Mandić ${ }^{1}$, Stefan Mandić-Rajčević2 ${ }^{2}$ Ljiljana Marković-Denić3 ${ }^{3}$ and Petar Bulat ${ }^{3,4}$ \\ Clinic of Hematology, Clinical Center Serbia ${ }^{l}$, Innovation Centre of the Faculty of Technology and Metallurgy, \\ University of Belgrade 2 , Institute of Epidemiology, Faculty of Medicine, University of Belgrade ${ }^{3}$, Serbian Institute of \\ Occupational Health "Dr Dragomir Karajović", Belgrade, Serbia
}

[Received in September 2017; Similarity Check in September 2017; Accepted in February 2018]

\begin{abstract}
The risk of occupational bloodborne infections (HBV, HCV, and HIV) among healthcare workers remains a serious issue in developing countries. The aim of this study was to estimate occupational exposure to bloodborne infections among general hospital workers in Serbia. This cross-sectional study was conducted in the spring of 2013 and included 5,247 healthcare workers from 17 general hospitals. The questionnaire was anonymous, self-completed, and included sociodemographic information with details of blood and bodily fluid exposure over the career and in the previous year (2012). Significant predictors of sharps injuries were determined with multiple logistic regressions. The distribution of accidents in 2012 was equal between the genders (39\%), but in entire career it was more prevalent in women (67\%). The most vulnerable group were nurses. Most medical doctors, nurses, and laboratory technicians reported stabs or skin contact with patients' blood/other bodily fluid/tissue as their last accident. Healthcare workers from the north/west part of the country reported a significantly lower number of accidents over the entire career than the rest of the country $(p<0.001)$. The south of Serbia stood out as the most accident-prone in $2012(\mathrm{p}=0.042)$.
\end{abstract}

KEY WORDS: bloodborne infections; occupational risk; predictive modelling; sharps injuries

Every working day, over 59 million healthcare workers $(\mathrm{HCW})$ in the world run the risk of getting infected with hepatitis, AIDS, or tuberculosis by accidental exposure to patient's blood and other bodily fluids (1). This global issue is even more pronounced in developing countries, where the risk is underappreciated, overlooked, and poorly prevented. There are currently more than 90,000 healthcare workers in Serbia, 22 thousand of whom are medical doctors and 62 thousand nurses (2).

The most common sources of exposure to bloodborne infections in the healthcare sector are needlestick and sharps injuries. Sharps injuries include stabs or cuts with a sharp object, such as syringe or surgical needles, scalpels, lancets, or broken glass. However, they are not the only way of exposure to patient's blood or bodily fluids. Others include exposure through mucosa or skin damaged in some other way. Global estimates from a decade ago speak of $0.18-4.68$ sharps injuries per healthcare worker a year (3). For the countries of the EUR B region, which includes Serbia (former Yugoslavia), the number of sharp injuries was almost one. These injuries were estimated to cause $690 \mathrm{HCV}, 6400 \mathrm{HBV}$, and 1 HIV infections among healthcare workers a year (3).

In May 2010, the European Union implemented the Framework Agreement on prevention of sharps injuries in the hospitals and healthcare sector by Council directive

Correspondence to: Bojana Mandić, Clinic of Hematology, Clinical Center Serbia, Dr. Koste Todorovića 2, Belgrade, Serbia

E-mail: mandicbojana@yahoo.com
2010/32/EU (4). This document contains necessary information about occupational sharps injuries. Not being a member state yet, Serbia is not obliged to nor has it kept a national record of occupational blood and infectious bodily fluid exposures, including those involving occupational needlestick injuries and injuries due to sharps or splashes of blood/bodily fluids. It does not even have national guidelines for post-exposure prophylaxis.

Only a few cross-sectional studies have been conducted in Serbia on sharp injuries or splash exposures among healthcare workers, those in 2003 (5), 2011 (6), and 2012 (7). However, their findings are limited by an unrepresentative sample, which was modest in the number of participants, covered only some departments, did not distinguish between primary, secondary, and tertiary healthcare services, and was not nationwide.

The aim of our study was to make up for this lack of information with a new and comprehensive, nationwide survey of occupational sharps injuries and splash exposures, so as to have some baseline information by the time Serbia adopts the Council directive 2010/32/EU (4). This study makes part of a bigger survey of occupational sharps injuries among healthcare workers (HCWs) in Southeast Europe.

\section{PARTICIPANTS AND METHODS}

This cross-sectional survey was conducted in 17 (of 36) Serbian general hospitals in the spring of 2013 and included 
HCWs who routinely work with blood (physicians, nurses, laboratory technicians, and support staff such as cleaners and workers in laundry and sterilisation). We used a geographically stratified design, with Serbia divided into six regions. Our random selection included one hospital from the west of Serbia, four from the east, two from central Serbia, two from the south, four from Vojvodina, and four from Belgrade. Ethics committees and/or responsible persons from the management of each hospital approved the survey.

The questionnaire was based on a Croatian selfreporting questionnaire on exposure to bloodborne infections (8) and on a questionnaire previously used in Serbia (7). To test the questionnaire, we ran a pilot study at the Serbian Institute of Occupational Health (data not presented) and revised it to improve clarity for HCWs.

The final questionnaire contained 34 multiple-choice questions adjusted to Serbian population. It was anonymous, and all participants were informed about its aim and instructed how to complete it.

The information collected included socio-demographic data such as age, gender, education level, specialty (for physicians), hospital department, the number of blood and bodily fluid (BBF) exposures over the entire career (expressed as none, one, or more than one), and details about exposures in 2012. Details about the most recent accident included the type of activity preceding the accident, objects and instruments involved, patient's $\mathrm{HIV} / \mathrm{HBV} / \mathrm{HCV}$ status, hours on duty, and whether the accidents were reported or not. The questionnaire also investigated how much the participants knew about the health risks from BBF exposure, whether they were vaccinated against $\mathrm{HBV}$, and which post-exposure treatment they received.

The questionnaire was answered by 5,762 participants (response rate $88 \%$ ), but we excluded 515 participants who did not fill more than $50 \%$ of the questionnaire. The analysis, therefore, included the answers of 5,247 participants, who submitted completed or partly incomplete forms. Hence the difference in total numbers of respondents to specific questions.

\section{Data management and analysis}

The questionnaire forms were created and answers scanned with the Remark optical mark recognition software (Remark Office OMR ${ }^{\circledR}$, Remark, Mulvern, PA, USA). Readings were stored in Microsoft Excel spreadsheets (Microsoft, Redmond, WA, USA).

The chi-square and Fisher's exact test were used to look for associations between reported sharps injuries and variables such as demographic, workplace, and workday characteristics over the previous year (2012) and the entire career.

Multivariate logistic regression was used to evaluate the strength of association between these variables and identify the most important predictors of increased BBF exposure in HCWs over the career and in 2012. Belgrade (the capital) was selected as the reference region for calculating predictors, being the most advanced in equipment and training in the country. Other reference variables were the lowest age and work experience groups.

Statistical analysis was done using the IBM SPSS Statistics for Windows, Version 22.0 (IBM Corp, Armonk, NY, USA).

\section{RESULTS AND DISCUSSION}

Table 1 shows the demographic information about the study population. Their characteristics were fairly similar across the six regions, with deviation lower than $10 \%$.

Nearly $66 \%$ of the respondents reported at least one BBF exposure in their career, and $39 \%$ reported at least one such accident in 2012 (Table 2). Compared to the neighbouring and EU countries, our one-year BBF exposure prevalence among HCWs was lower than in Montenegro (9) and France (10), but higher than in Bosnia and Herzegovina (11) and Germany (12).

Another Serbian study (6) reported much lower career and one-year prevalence (35\% and $26 \%$, respectively) in university hospitals than in general hospitals and clinics. Similar was observed in the 2004 French study referenced above (10). Perhaps university hospitals have better medical equipment, devices, or safety measures than general hospitals.

The 2012 exposure prevalence varied across the Serbian regions $(\mathrm{p}<0.001)$ with south Serbia reporting the highest $(49 \%)$. This may point to safety training issues, work overload, or weaker management, organisation and financial support. Some of the issues can be cost-effectively addressed by quality training programmes for HCWs.

The distribution of accidents in 2012 was equal between the genders (39\%). Over the entire career, however, it was significantly more prevalent in women $(\mathrm{p}<0.05)$.

As expected, the prevalence was higher in the surgical specialties (surgery, gynaecology and anaesthesiology) and in respondents working in the operating room $(60 \%)$, intensive care unit (48\%), dialysis ward (45\%), and delivery room $(43 \%)$.

Table 3 shows the details about BBF exposure accidents in 2012 and differences in their prevalence between medical doctors, nurses/lab workers, and other occupations. If more than one accident had been reported, only the details of the last accident were collected. As expected, the most frequent types of accident were stabs and blood-skin contact. The latter suggests that many Serbian HCWs do not wear protective gloves.

Most participants reported that their last accident happened during blood draw $(18 \%)$ or while preparing to insert the needle in a patient $(17 \%)$.

Most medical doctors had the latest BBF exposure during surgery (55\%), whereas most nurses and laboratory 
若

$\frac{\dot{m}}{\dot{m}} \fallingdotseq$

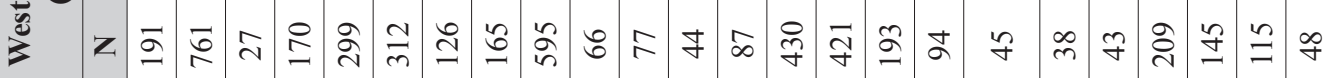

.

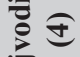

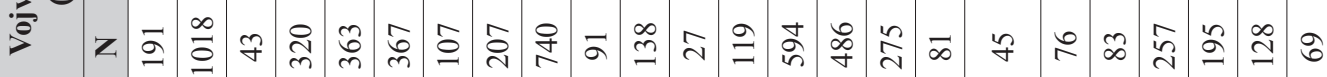

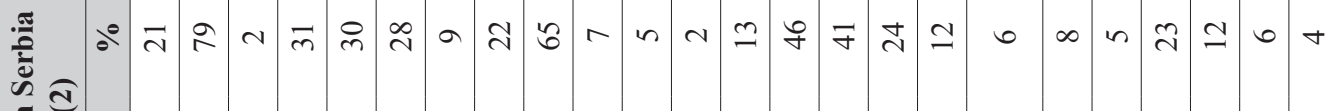

竞 z

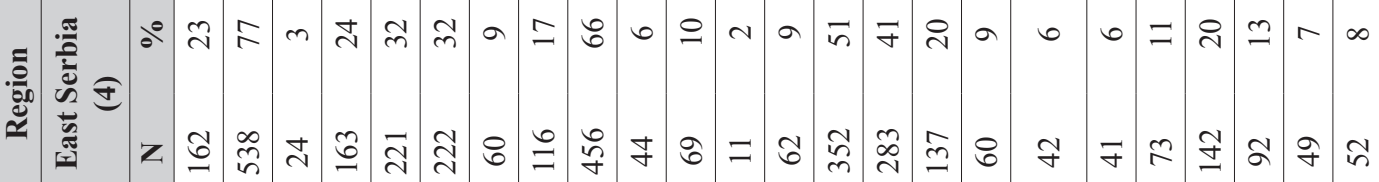

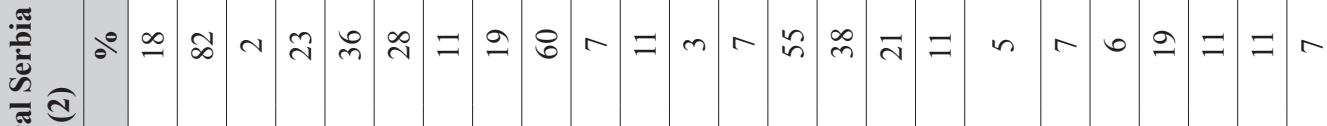

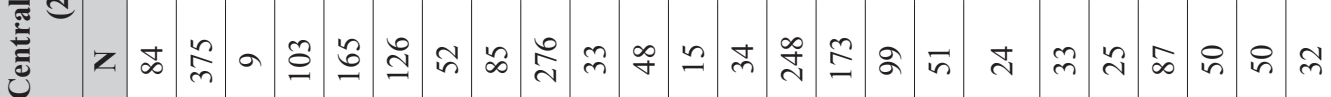

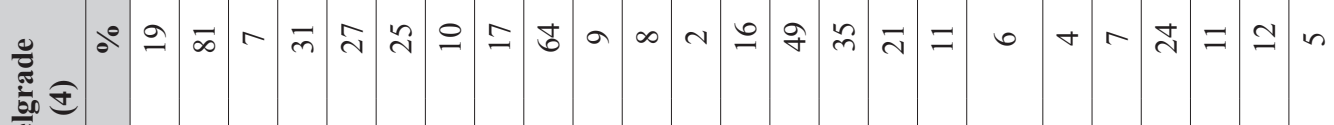

舟

玹

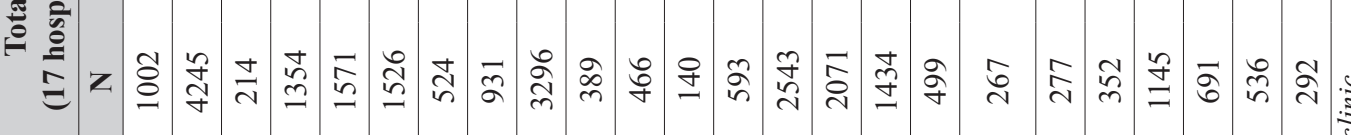

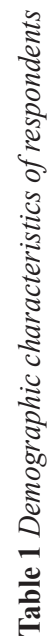

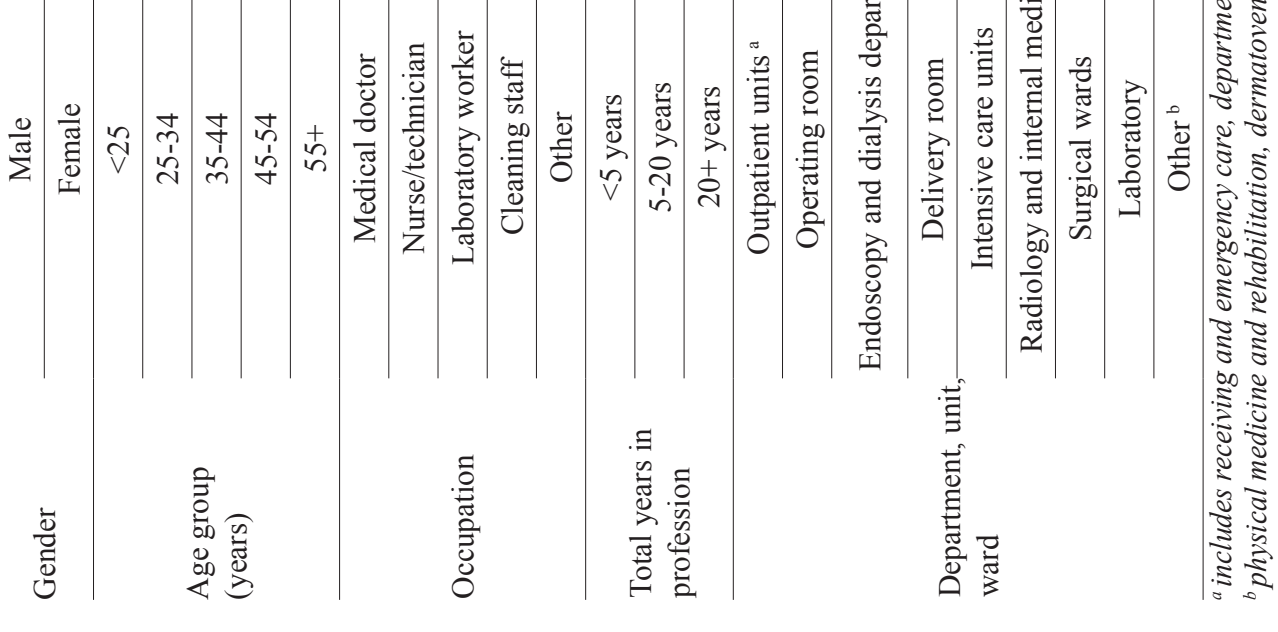

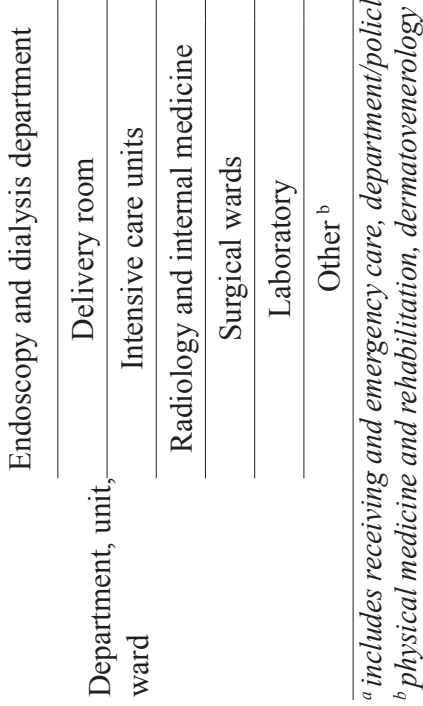


Table 2 Prevalence of accidents by variables

\begin{tabular}{|c|c|c|c|c|c|c|c|}
\hline & & \multicolumn{3}{|c|}{ Career prevalence } & \multicolumn{3}{|c|}{ One-year prevalence (2012) } \\
\hline & & $\mathbf{N}$ & $\%$ & p-value & $\mathbf{N}$ & $\%$ & p-value \\
\hline \multirow{7}{*}{ Region } & Total & 3439 & 66 & & 2066 & 39 & \\
\hline & Belgrade & 971 & 69 & & 588 & 41 & \\
\hline & Central Serbia & 321 & 70 & & 199 & 43 & \\
\hline & East Serbia & 480 & 69 & $<0.05$ & 291 & 42 & $<0.05$ \\
\hline & South Serbia & 348 & 69 & & 251 & 49 & \\
\hline & Vojvodina & 785 & 65 & & 457 & 38 & \\
\hline & West Serbia & 534 & 57 & & 280 & 29 & \\
\hline \multirow{2}{*}{ Gender } & Men & 608 & 61 & $<0.05$ & 393 & 39 & 0.945 \\
\hline & Women & 2821 & 67 & & 1670 & 39 & \\
\hline \multirow{5}{*}{$\begin{array}{l}\text { Age group } \\
\text { (years) }\end{array}$} & $<25$ & 115 & 55 & & 88 & 41 & \\
\hline & $25-34$ & 911 & 68 & & 630 & 47 & \\
\hline & $35-44$ & 1073 & 69 & $<0.05$ & 597 & 38 & $<0.05$ \\
\hline & $45-54$ & 976 & 65 & & 560 & 37 & \\
\hline & $55+$ & 318 & 61 & & 164 & 31 & \\
\hline \multirow{5}{*}{ Job title } & Medical doctor & 503 & 54 & & 336 & 36 & \\
\hline & Nurse & 2350 & 72 & & 1413 & 43 & \\
\hline & Laboratory technician & 263 & 68 & $<0.05$ & 150 & 39 & $<0.05$ \\
\hline & Cleaning staff & 242 & 55 & & 125 & 27 & \\
\hline & Other ${ }^{a}$ & 57 & 42 & & 31 & 22 & \\
\hline \multirow{3}{*}{$\begin{array}{l}\text { Work experience } \\
\text { (years }\end{array}$} & $<5$ & 328 & 56 & & 256 & 43 & \\
\hline & $5-20$ & 1723 & 68 & $<0.05$ & 1061 & 42 & $<0.05$ \\
\hline & $20+$ & 1360 & 67 & & 733 & 35 & \\
\hline \multirow{2}{*}{ Specialty } & Nonsurgical & 1635 & 63 & & 963 & 36 & \\
\hline & Surgical & 1249 & 76 & $<0.05$ & 820 & 49 & $<0.05$ \\
\hline \multirow{9}{*}{$\begin{array}{l}\text { Department, unit, } \\
\text { ward }\end{array}$} & Outpatient units ${ }^{b}$ & 622 & 60 & & 325 & 96 & \\
\hline & Surgical room & 403 & 81 & & 301 & 60 & \\
\hline & Endoscopy and dialysis department & 202 & 72 & & 115 & 79 & \\
\hline & Delivery room & 177 & 65 & $<0.05$ & 119 & 43 & $<0.05$ \\
\hline & Intensive care units & 253 & 72 & & 168 & 48 & \\
\hline & Radiology and internal medicine & 737 & 59 & & 456 & 72 & \\
\hline & Surgical wards & 486 & 72 & & 298 & 43 & \\
\hline & Laboratory & 361 & 68 & & 193 & 36 & \\
\hline & Other $^{c}$ & 139 & 48 & & 67 & 23 & \\
\hline
\end{tabular}

${ }^{a}$ workers in laundry and sterilisation

${ }^{b}$ includes receiving and emergency care, department/policlinic

${ }^{c}$ physical medicine and rehabilitation, dermatovenerology

${ }^{d}$ Chi-square test of association

technicians reported exposure during blood draw (21\%) and recapping (19\%). We can only speculate why, as we did not collect a detailed description of the procedures. Perhaps some hospitals still draw blood with a syringe instead of vacutainer tubes, which are much safer to use. As for recapping, our findings are much higher than the reports from Poland (6.9\%) (13) and France (5.9\%) (10), even though many Serbian hospitals have guidelines for safe needle disposal.

Our results, however, single out one group as highly at risk of stabs: the so called "others", the support staff: cleaners, launderers, and sterilisation room attendants. This group has reported the highest rate of stabs of all, as well as the highest rate of $\mathrm{BBF}$ exposure during disposal of sharps and waste and during cleaning. They most consistently pointed their finger to inappropriate waste disposal and disregard of other staff (medical doctors and nurses/lab technicians) for them as the main causes of exposure. We believe that this group is quite neglected in 


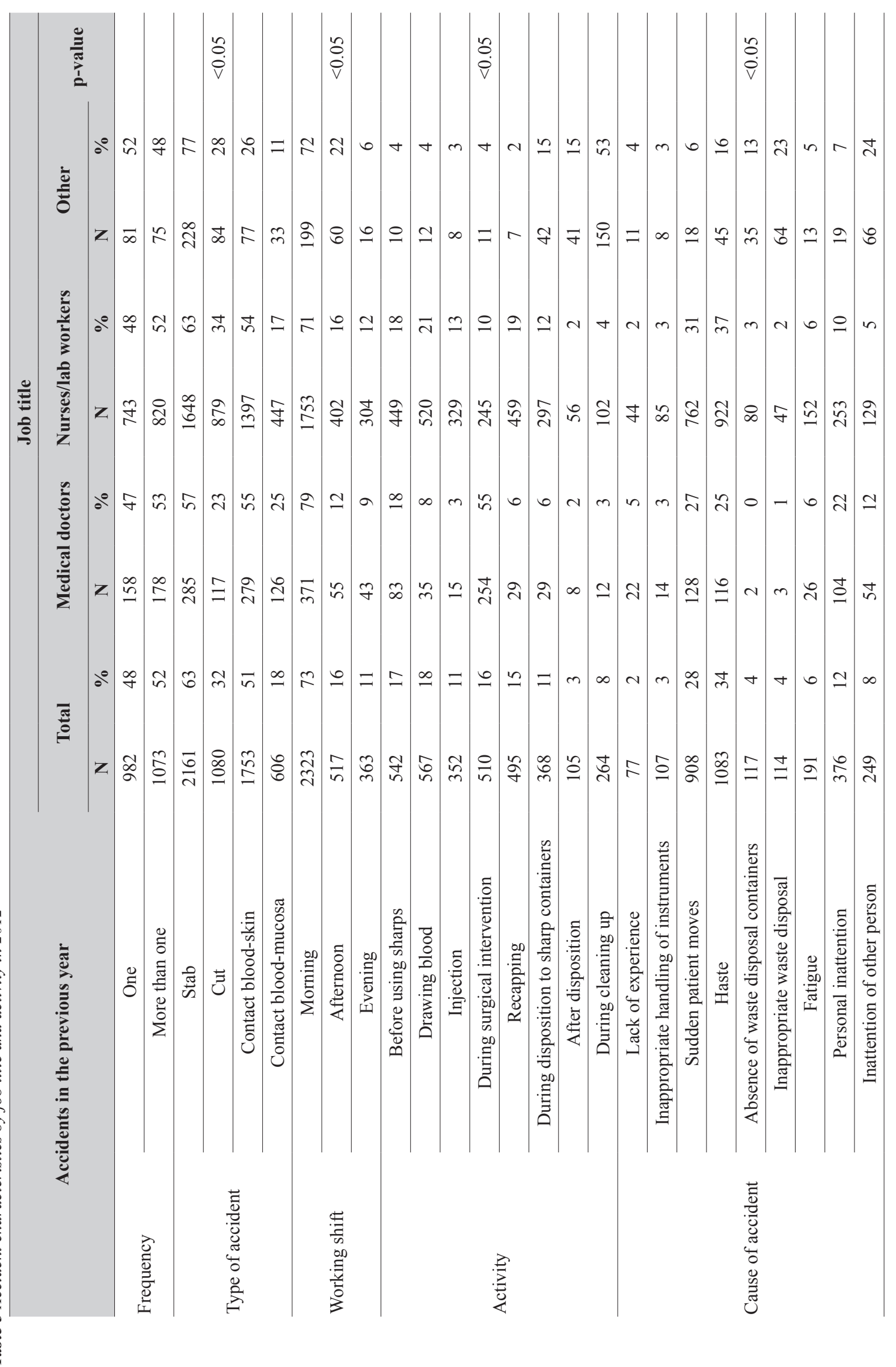


Table 4 Predictive significance of variables for BBF exposure over the entire career

\begin{tabular}{|c|c|c|c|c|c|}
\hline & & \multirow{2}{*}{$\mathbf{P}$} & \multirow{2}{*}{ OR } & \multicolumn{2}{|c|}{$95 \%$ CI for OR } \\
\hline & & & & Lower & Upper \\
\hline \multirow{6}{*}{ Region } & Belgrade (ref) & 0.000 & & & \\
\hline & Central Serbia & 0.036 & .752 & .575 & .982 \\
\hline & East Serbia & 0.374 & .900 & .712 & 1.136 \\
\hline & South Serbia & 0.194 & .847 & .660 & 1.088 \\
\hline & Vojvodina & 0.000 & .683 & .561 & .832 \\
\hline & West Serbia & 0.000 & .495 & .404 & .607 \\
\hline Gender & Gender (Female) & 0.227 & 1.113 & .936 & 1.324 \\
\hline \multirow{5}{*}{ Age } & $<25$ (ref) & 0.200 & & & \\
\hline & $25-34$ & 0.234 & 1.244 & .868 & 1.781 \\
\hline & $35-44$ & 0.057 & 1.474 & .989 & 2.198 \\
\hline & $45-54$ & 0.069 & 1.503 & .969 & 2.332 \\
\hline & $55+$ & 0.286 & 1.306 & .800 & 2.132 \\
\hline \multirow{3}{*}{ Job title } & Medical doctor & 0.000 & & & \\
\hline & Nurse/laboratory technician & 0.000 & 2.165 & 1.813 & 2.584 \\
\hline & Other $^{\mathrm{a}}$ & 0.607 & .912 & .642 & 1.296 \\
\hline \multirow{3}{*}{ Work experience } & $<5$ years & 0.001 & & & \\
\hline & $5-20$ years & 0.000 & 1.629 & 1.263 & 2.101 \\
\hline & $20+$ years & 0.017 & 1.487 & 1.074 & 2.058 \\
\hline \multirow[t]{2}{*}{ Specialty } & Surgical branches & 0.000 & 1.915 & 1.656 & 2.215 \\
\hline & Constant & 0.003 & .577 & & \\
\hline
\end{tabular}

${ }^{a}$ Support staff, (cleaners, workers in laundry and sterilisation)

OR - odds ratio

$C I$ - confidence interval

terms of safety instructions and procedures, as they are not directly involved in medical care, and this issue needs to be addressed in every hospital.

That accidents prevail in the morning shift $(73 \%)$ is not a surprise, as morning shifts see much more activity. Some studies (14) have shown the evening shift as critical, but most other studies worldwide report results consistent with ours $(7,15,16)$.

The main cause of accidents is haste, especially among nurses, followed by sudden patient moves. Medical doctors are the group that most often reported their own inattention as the cause of BBF exposure of all groups.

Tables 4 and 5 show which of the variables stand out as significant predictors of BBF exposure over the entire career and in 2012, respectively. Compared to Belgrade, only Vojvodina (highly developed northern region of Serbia) and west Serbia had significantly (30-50 \%) lower odds of BBF exposure over the entire career. In 2012, south Serbia had significantly $(20 \%)$ higher, and west Serbia significantly (35\%) lower odds of BBF exposure. For now, we can only speculate about the reasons for these differences.

Gender was not a significant predictor of BBF exposure, and, interestingly, neither was age. In contrast, work experience longer than five years turned out to be a significant BBF exposure predictor over the entire career, which is expected, as the risk grows over the years. In 2012, however, work experience was not a significant predictor of BBF exposure, which also makes sense, as experienced staff makes fewer mistakes.

Nurses and laboratory technicians had double the odds of medical doctors having BBF exposure over the career, but only $30 \%$ higher odds in 2012 .

The odds of BBF exposure over the career were twice as high in the surgical branches vs. non-surgical ones, and $65 \%$ higher in 2012. The most vulnerable working places in general hospitals were operating rooms, which was also reported by Treakle (17) and Jagger (18).

There are several limitations to this study, as it has not investigated the incidence of sharps injuries or how frequently HCWs come in contact with blood or bodily fluid on a daily basis. Despite these limitations, our study boasts a large sample size and gives a relatively reliable idea about the current state of BBF exposure in Serbian general hospitals. By pinpointing significant predictors (bolded in Tables 4 and 5), this study has singled out safety issues for specific geographical areas, medical branches, and working groups that need addressing, at least in the form of raising awareness of exposure risks. The results of our study can also serve as a baseline for future longitudinal studies as part of the EU "Framework Agreement on prevention of sharps injuries in the hospital and healthcare sector". 
Table 5 Predictive significance of variables for BBF exposure in 2012

\begin{tabular}{|c|c|c|c|c|c|}
\hline & & \multirow{2}{*}{$\mathbf{P}$} & \multirow{2}{*}{ OR } & \multicolumn{2}{|c|}{$95 \%$ CI for OR } \\
\hline & & & & Lower & Upper \\
\hline \multirow{6}{*}{ Region } & Belgrade (ref) & 0.000 & & & \\
\hline & Central Serbia & 0.839 & 1.026 & .804 & 1.309 \\
\hline & East Serbia & 0.825 & 1.024 & .832 & 1.260 \\
\hline & South Serbia & 0.042 & 1.262 & 1.009 & 1.579 \\
\hline & Vojvodina & 0.076 & .849 & .709 & 1.017 \\
\hline & West Serbia & 0.000 & .633 & .521 & .769 \\
\hline \multirow[t]{3}{*}{ Gender } & Gender $(\mathrm{F})$ & 0.690 & 1.034 & .876 & 1.222 \\
\hline & $<25$ (ref) & 0.195 & & & \\
\hline & $25-34$ & 0.465 & 1.139 & .803 & 1.615 \\
\hline \multirow[t]{4}{*}{ Age } & $35-44$ & 0.913 & .979 & .668 & 1.435 \\
\hline & $45-54$ & 0.548 & 1.137 & .747 & 1.730 \\
\hline & $55+$ & 0.763 & .929 & .578 & 1.496 \\
\hline & Medical doctor (ref) & 0.000 & & & \\
\hline \multirow[t]{3}{*}{ Job title } & Nurse/ laboratory technician & 0.004 & 1.294 & 1.087 & 1.541 \\
\hline & Other $^{\mathrm{a}}$ & 0.035 & .663 & .452 & .971 \\
\hline & $<5$ years (ref) & 0.018 & & & \\
\hline \multirow[t]{2}{*}{ Work experience } & $5-20$ years & 0.936 & 1.010 & .793 & 1.286 \\
\hline & $20+$ years & 0.069 & .752 & .553 & 1.023 \\
\hline \multirow[t]{2}{*}{ Specialty } & Surgical branches & 0.000 & 1.663 & 1.462 & 1.892 \\
\hline & Constant & 0.001 & .543 & & \\
\hline
\end{tabular}

\section{Acknowledgements}

The research presented in this paper has been done as part of the TR 34009, ON 175036, and TR 1653014 projects, funded by the Ministry of Education, Science and Technological Development of the Republic of Serbia. We thank all healthcare workers who participated in this survey.

\section{REFERENCES}

1. World Health Organization (WHO). Occupational health Health workers [displayed 28 May 2017]. Available at http:// www.who.int/occupational_health/topics/hcworkers/en/

2. Institute of Public Health of Serbia "Dr. Milan Jovanović Batut". Health statistical yearbook of Republic of Serbia [displayed 21 Jul 2017]. Available at http://www.batut.org. rs/index.php?category_id $=132 \&$ month $=10 \&$ year $=2017$

3. Rapiti E, Prüss-Üstün A, Hutlin Y. Sharps injuries: Assessing the burden of disease from sharps injuries to health-care workers at national and local levels. WHO Environmental burden of disease series No. 11, 2005 [displayed 28 May 2017]. Available at http://www.who.int/quantifying ehimpacts/publications/ebd11.pdf

4. Council Directive 2010/32/EU of 10 May 2010 implementing the Framework Agreement on prevention from sharp injuries in the hospital and healthcare sector concluded by HOSPEEM and EPSU [displayed 23 November 2017]. Available at http://
eur-1ex.europa.eu/LexU-riServ/LexUriServ. do?uri=OJ:L:2010:134:0066:0072:EN:PDF

5. Jovic-Vranes A, Jankovic S, Vranes B. Safety practice and professional exposure to blood and blood-containing materials in Serbian health care workers. J Occup Health 2006;48:377-82. doi: 10.1539/joh.48.377

6. Marković-Denić L, Branković M, Maksimović N, Jovanović B, Petrović I, Simić M, Lesić A. Occupational exposures to blood and body fluids among health care workers at university hospitals. Srp Arh Celok Lek 2013;141:789-93. doi: 10.2298/ SARH1312789M

7. Markovic-Denic L, Maksimovic N, Marusic V, Vucicevic J, Ostric I, Djuric D. Occupational exposure to blood and body fluids among health-care workers in Serbia. Med Princ Pract 2015;24:36-41. doi: 10.1159/000368234

8. Obad I, Papeš D, Čivljak R, Milošević M, Stamenić V, Kalenić S. Procjena profesionalne izloženosti infekcijama koje se prenose krvlju u djelatnika ginekološko-porodiljskih odjela u Hrvatskoj [Assessment of occupational exposure to blood borne infections among personnel at obstetrics and gynecology departments in Croatia, in Croatian]. Infektol glasn 2012;32:159-66.

9. Cvejanov-Kezunović L, Mustajbegović J, Milošević M, Čivljak R. Occupational exposure to blood among hospital workers in Montenegro. Arh Hig Rada Toksikol 2014;65:27380. doi: 10.2478/10004-1254-65-2014-2493

10. Venier AG, Vincent A, L'heriteau F, Floret N, Senechal H, Abiteboul D, Reyreaud E, Coignard B, Parneix P. Surveillance 
of occupational blood and body fluid exposures among French healthcare workers in 2004. Infect Control Hosp Epidemiol 2007;28:1196-201. doi: 10.1086/520742

11. Musa S, Peek-Asa C, Young T, Jovanovic N. Needle stick injuries, sharp injuries and other occupational exposures to blood and body fluids among health care workers in a general hospital in Sarajevo, Bosnia and Herzegovina. Int J Occup Saf Health 2014;4:31-7. doi: 10.3126/ijosh.v4i1.9847

12. Wicker S, Jung J, Allwinn R. Gottschalk R, Rabenau HF. Prevalence and prevention of needlestick injuries among health care workers in a German university hospital. Int Arch Occup Environ Health 2008;81:347-54. doi: 10.1007/ s00420-007-0219-7

13. Leszczyszyn-Pynka M, Kłys-Rachwalska M, Sacharczuk B, Boroń-Kaczmarska A. Occupational exposure to human immunodeficiency virus (HIV) - how can we reduce the risk? Int J Occup Saf Ergonom 2004;10:425-9.

14. Rajkumari N, Thanbuana BT, John NV, Gunjiyal J, Mathur P, Misra MC. A prospective look at the burden of sharps injuries and splashes among trauma health care workers in developing countries: True picture or tip of iceberg. Injury 2014;45:1470-8. doi: 10.1016/j.injury.2014.03.001

15. Ghannad MS, Majzoobi MM, Ghavimi M, Mirzaei M. Needlestick and sharp object injuries among health care workers in Hamadan Province, Iran. J Emerg Nurs 2012:38:171-5. doi: 10.1016/j.jen.2011.01.009

16. Kasatpibal N, Whitney JD, Katechanok S, Ngamsakulrat S, Malairungsakul B, Sirikulsathean P, Nuntawinit C, Muangnart T. Prevalence and risk factors of needlestick injuries, sharps injuries, and blood and body fluid exposures among operating room nurses in Thailand. Am J Infect Control 2016;44:85-90. doi: 10.1016/j.ajic.2015.07.028

17. Treakle AM, Schultz M, Giannakos GP, Joyce PC, Gordin FM. Evaluating a decade of exposures to blood and body fluids in an inner-city teaching hospital. Infect Control Hosp Epidemiol 2011;32:903-7. doi: 10.1086/661281

18. Jagger J, Berguer R, Phillips EK, Parker G, Gomaa AE. Increase in sharps injuries in surgical settings versus nonsurgical settings after passage of national needlestick legislation. J Am Coll Surg 2009;210:496-502. doi: 10.1016/j. jamcollsurg.2009.12.018

\section{Profesionalna izloženost krvi i tjelesnim tekućinama zdravstvenih radnika u općim bolnicama u Srbiji}

Rizik od profesionalnih krvnoprenosivih bolesti (HBV, HCV, HIV) među zdravstvenim radnicima i dalje je ozbiljan problem u zemljama u razvoju. Cilj presječnoga ispitivanja, koje je provedeno u proljeće 2013. i u kojem je sudjelovalo 5.247 ispitanika iz 17 općih bolnica, bio je procijeniti profesionalnu izloženost zdravstvenih radnika u Srbiji krvnoprenosivim bolestima. Upitnik je bio anoniman i sadržavao je opće podatke i podatke o prethodnoj izloženosti krvi i tjelesnim tekućinama. Korištena je analiza multiple logističke regresije za određivanje značajnih prediktivnih čimbenika ubodnih incidenata. U prethodnoj godini broj ozljeda bio je jednak i u muškoj i u ženskoj populaciji (39 \%), a tijekom cijelog radnog staža prevalencija je bila viša u ženskoj populaciji (67 \%). Najveći broj ozljeda imale su medicinske sestre/ tehničari. Najveći broj liječnika, medicinskih sestara i laboratorijskih radnika kao posljednji incident navode ubod ili kontakt kože s krvlju pacijenta, drugim tjelesnim tekućinama ili tkivima. Razlike među regijama bile su značajne u sjevernom/zapadnom području Srbije, gdje je rizik od incidenata bio niži tijekom cijelog radnog staža $(p<0,001)$, i na jugu, gdje je rizik tijekom prethodne godine bio povišen $(p=0,042)$. 